Tersedia Online di http://journal.unismuh.ac.id/index.php/otoritas

Otoritas : Jurnal Ilmu Pemerintahan, 7 (1), April 2017, 14-18

\title{
Patologi Birokrasi Yang Dimanifestasikan Dalam Perilaku Birokrat Yang Bersifat Disfungsional
}

\author{
Hamirul*) \\ Fakultas Ekonomi, Universitas Putra Indonesia, Jalan Dr. Muwardi No.66 Bypass Cianjur 46113, \\ Jawa Barat, Indonesia
}

Diterima : 18 Januari 2017; Disetujui : 3 Maret 2017; Dipublikasikan 14 April 2017

\begin{abstract}
The main problem of this article is to identify the type of pathology experienced by the Cimahi city land office, as well as what strategies can be applied in order to minimize the pathology manifested in dysfunctional or negative behaviors. The results of research at Cimahi urban land office in serving the public still suffer from the type of bureaucratic pathology manifested in bureaucratic behavior that is dysfunctional or negative, such as: no discipline, pretending to be busy, abetting and cooperating with brokers, arrogance. Some strategies that can be done in minimizing this type of pathology is the transparency of time and costs in administering the certificate by strengthening the administration, strengthening the bureaucracy itself both individually by improving the quality of human resources and organizational with a structural approach, technological approach, approach that focuses on Performance and approach of people religiously, psychologically and kesisteman by using one-stop service system or one stop service.
\end{abstract}

Keywords: Bureaucracy Pathology; Bureaucracy; Excellent Service

\begin{abstract}
Abstrak
Permasalahan pokok dalam artikel ini adalah untuk mengidentifikasi jenis patologi yang dialami kantor pertanahan kota Cimahi, serta strategi apa yang dapat diterapkan dalam rangka meminimalisir patologi yang dimanifestasikan dalam perilaku yang bersifat disfungsional atau negatif. Hasil penelitian dikantor pertanahan kota Cimahi dalam melayani publik masih menderita jenis patologi birokrasi yang dimanifestasikan dalam perilaku birokrat yang bersifat disfungsional atau negatif, diantaranya:tidak disiplin, berpura-pura sibuk, bersekongkol dan bekerjasama dengan calo, arogansi. Beberapa strategi yang dapat dilakukan dalam meminimalisir patologi jenis ini yakni dengan transparansi waktu serta biaya dalam mengurus sertifikat dengan penguatan administrasi, penguatan birokrasi itu sendiri baik individu dengan cara meningkatkan kualitas sumberdaya manusianya dan secara organisasi dengan pendekatan secara struktural, pendekatan teknologi, pendekatan yang berfokus pada kinerja serta pendekatan orang secara kagamaan, secara psikologis dan secara kesisteman dengan menggunakan sistem pelayanan satu atap atau one stop service.
\end{abstract}

Kata kunci : Patologi Birokrasi; Birokrasi; Pelayanan Prima

Cara Penulisan Sitasi : Hamirul, H. (2017). Patologi Birokrasi Yang Dimanifestasikan Dalam Perilaku Birokrat Yang Bersifat Disfungsional. Otoritas : Jurnal Ilmu Pemerintahan, 7 (1), 14-18.

*)Penulis Korespondensi.

E-Mail : hrul@ymail.com

Copyright @ 2017, Otoritas : Jurnal Ilmu Pemerintahan, p-ISSN: 2088-3706, e-ISSN: 2502-9320 
Tersedia Online di http://journal.unismuh.ac.id/index.php/otoritas

Otoritas : Jurnal Ilmu Pemerintahan, 7 (1), April 2017, 15

\section{Pendahuluan}

Manajemen profesional pelayanan publik harus lebih berorientasi pada tujuan paradigma pemerintahan yang didasarkan pada pendekatan manajemen baru, baik secara teori maupun praktis (Usman, 2011). Apalagi Permasalahan Birokrasi Publik Indonesia Bangsa Indonesia selalu dihadapkan kepada masalah bagaimana membangun pemerintahan yang bersih dan baik (good governance and clean government) (Lukman, 2016). Padahal Pelayanan publik sebagai bentuk pelayanan, baik dalam bentuk barang publik maupun jasa publik pada prinsipnya merupakan tanggung jawab administrasi publik dalam hal ini pemerintah pusat, daerah sampai level pemerintahan desa. Aktivitas pelayanan publik dilaksanakan dalam rangka pemenuhan kebutuhan masyarakat maupun pelaksanaan ketentuan perundang-undangan dan masalah pertanahan merupakan masalah utama yang harus dihadapi karena manusia tidak dapat dipisahkan dengan tanah, disamping itu masalah pertanahan adalah masalah pertambahan penduduk dimana setiap tahun jumlah penduduk semakin bertambah. Setiap manusia yang hidup ingin mempunyai tanah sendiri, sedangkan jumlah tanah yang ada tetap dan tidak akan bertambah.

Munculnya permasalahan pertanahan baik proses penyediaannya terlebih dalam hubungannya dengan status penggunaan tanah dengan berbagai perubahannya, maka akan berakibat pula pada semakin sulitnya penyelesaian permasalahan dalam proses pelayanan dibidang pertanahan. Disatu sisi disebabkan oleh semakin meningkatnya pelayanan dan dilain pihak aparat pertanahan juga dituntut untuk dapat memberikan pelayanan secara cepat, benar, murah, tepat waktu memuaskan dan menjamin kepastian hukum. Namun hal tersebut sangat bertolak belakang dengan pelayanan yang terjadi di kantor pertanahan kota Cimahi, bahkan menurut Usman (2011), kecenderungan birokrasi dan birokratisasi pada masyarakat modern benar-benar dipandang memprihatinkan. Selain itu tidak adanya transparansi dalam hal memberikan kejelasan waktu serta biaya dalam hal pengurusan sertifikat maupun perizinan menjadi patologi krusial yang menahun.

Artikel yang membahas terkait patologi birokrasi dibahas oleh Usman (2011) yang membahas tentang pentingnya menghadirkan manajemen profesional yang baru dalam penyelesaian permasalahan birokrasi. Pelayanan birokrat yang efektif dan efisien harus menjadi ciri institusi pemerintahan kekinian. Selain itu Lukman (2016) perlunya profesionalisme Aparatur Negara khususnya dalam hal responsivitas dan inovatif, selain itu perlu menetapkan dan menentukan standar mutu pelayanan yang aspiratif, responsif dan fleksibel, dengan konsekuensi birokrasi harus mematuhi standar mutu pelayanan tersebut secara konsisten. Bahkan Supardal (2016) membahas dalam artikelnya terkait pentingnya peran ICT dalam pelayanan publik sebagai solusi di era kekinian, birokrat harus piwai menggunakan kesempatan dalam penggunaan ICT dengan baik.

Adapun artikel ini bertujuan untuk membahas terkait patologi birokrasi yang dimanifestasikan dengan adanya perilaku birokrat yang bersifat disfungsional, selain itu penekanan pada penilaian bentuk terapi patologi birokrasi pada obyek penelitian, serta strategi pelayanan administrasi dalam meminimalisir patologi di tempat tersebut.

\section{Metode Penelitian}

Metode penelitian digunakan Mixed Method Triangulasi Konkuren, yaitu penelitian mendalam dengan cara menganalisis kedua metode baik kuantitatif maupun kualitatif kemudian keduanya di bandingkan (Creswell, 2009). Dari 
perbandingan ini sehingga diharapkan masing-masing jenis patologi terlihat jelas kemudian diberikan terapi yang sesuai jenis patologi ini serta diharapkan pelayanan prima dapat terwujud dilingkungan kantor pertanahan kota Cimahi, pada penelitian ini untuk responden pegawai kantor pertanahan berjumlah 42 orang dan 10 ordinary informan dan 1 orang key informan. Pengumpulan data dilakukan dengan menggunakan angket untuk metode kuantitatif sedangkan untuk metode kualitatif menggunakan interview serta dilengkapi dengan studi dokumentasi.

\section{Hasil dan Pembahasan}

Patologi birokrasi diidentifikasi oleh Siagian (1999) dalam lima kelompok yaitu, patologi yang timbul karena persepsi dan gaya manajerial para pejabat di lingkungan birokrasi, patologi yang disebabkan karena kurangnya atau rendahnya pengetahuan dan terampilan para petugas pelaksana berbagai kegiatan operasional, patologi yang timbul karena tindakan para aparat birokrasi yang melanggar norma-norma hukum dan peraturan perundang-undangan yang berlaku, patologi yang dimanifestasikan dalam perilaku para birokrat yang bersifat disfungsional atau negatif, dan patologi yang merupakan akibat situasi internal dalam berbagai instansi dalam lingkungan pemerintahan.

Perilaku birokrasi yang bersifat patologis bukanlah merupakan hal yang berdiri sendiri, tetapi merupakan hasil interaksi antara berbagai aspek, seperti aspek birokrasi dan aspek individu yang ada dalam lingkungan. Aspek individu membawa ke tatanan birokrasi, kemampuan, kepercayaan pribadi, pengharapan, kebutuhan, dan pengalaman masa lainnya. Ini semua merupakan karakteristik individu, sedangkan karakteristik birokrasi terdiri dari susunan hirarki, adanya pembagian kerja, adanya tugastugas dalam jabatan tertentu, adanya wewenang dan tanggung jawab, adanya sistem penggajian tertentu, adanya sistem pengendalian. Jika karakteristik individu yang dikemukakan berinteraksi dengan karakteristik birokrasi, maka timbullah perilaku birokrasi (Sartika, 2013).

Sebagaimana hasil penelitian, patologi yang dimanifestasikan dalam perilaku yang bersifat disfungsional ditemukan antara lain, tidak disiplin, berpura-pura sibuk, bersekongkol bekerjasama dengan calo, adanya arogansi dari birokrat sehingga perlu adanya peraturan yang jelas serta diterapkan adanya Reward bagi keberhasilan birokrat dan perlunya pemberian hukuman agar dapat terkontrol dan kejadian yang bersifat negatif tidak terulang.

Pada kantor pertanahan kota Cimahi, posisi birokrasi sebagai abdi negara dan abdi masyarakat. Dengan predikat demikian mereka diharapkan akan dituntut menampilkan perilaku yang sesuai dengan peranannya selaku abdi tersebut. Maka Manusia adalah salah satu faktor penting dalam organisasi. Kinerja organisasi sangat tergantung pada kinerja individu yang ada di dalamnya (Rislan, 2016). Maka keseluruhan perilaku para anggota birokrasi tercermin pada pelayanan yang diberikan kepada masyarakat. Karena penerapan fungsi prinsip fungsionalisasi, spesialisasi dan pembagian tugas, sudah barang tentu terdapat bagian dari masyarakat yang menjadi klien suatu instansi tetentu. Sebagai prinsip dapat dikatakan bahwa pelayanan yang diberikan birokrasi kepada para klien harus bersifat adil, cepat ramah dan tanpa diskriminasi dan tanpa pilih kasih.

Pemahaman perilaku dalam kaitannya dengan patologi birokrasi, mutlak perlu disorot dari sudut pandang etos kerja dan kultur organisasi yang berlaku dalam kantor pertanahan kota Cimahi telah dimaklumi bahwa kultur organisasi suatu birokrasi tak bisa dilepaskan dari kultur sosial dimasyarakat luas. Kultur organisasi penting dipahami karena ber- 
peran antara lain sebagai alat pengendali perilaku para anggota birokrasi pemerintahan. Dikatakan demikian karena organisasi turut menentukan apa yang baik dan tidak baik, yang boleh dan dilarang, hal-hal yang dipandang wajar dan tidak wajar. Agar diakui dan diterima sebagai anggota birokrasi yang baik, perilaku yang dituntut dari padanya adalah sesuai dengan kultur yang dianut oleh Birokrat pada Kantor Pertanahan Kota Cimahi.

Mematuhi disiplin organisasi merupakan salah satu persyaratan yang mutlak ditaati oleh semua aparatur pemerintah, kepatuhan pada disiplin organisasi menyangkut berbagai sisi seperti ketaatan pada peraturan perundang-undangan yang berlaku, kehadiran tepat waktu ditempat tugas, kepatuhan kepada atasan, bekerja berdasarkan kultur organisasi yang disepakati bersama, menjunjung tinggi etos kerja dan tidak berperilaku negatif. Setiap bentuk tindakan dari perilaku yang menyimpang dari hal-hal yang negatif dapat digolongkan dalam pelanggaran disiplin.

Terapi yang dapat dilakukan untuk meminimalisir patologi birokrasi yang ada di kantor Pertanahan kota Cimahi perlu dilakukan langkah-langkah yang konkret bukan hanya sebagai retorika semata dan masalah transparansi baik waktu serta biaya dalam pelayanan seharusnya dijelaskan pada saat masyarakat mendaftarkan sertifikat yang diinginkan dengan adanya akses teknologi informasi dapat terwujudnya transparansi serta lebih mempercepat proses pelayanan. Penegasan tindakan bagi pegawai yang inkompetensi harus sesuai dengan pedoman right man on the right place sehingga tidak banyak terjadi kesalahan dalam hal pelayanan terhadap masyarakat serta pengisian atau rekruitmen jabatan, begitu pula dengan batasan serta wewenang dan tanggung jawab dalam hal jabatan, persyaratan jabatan, penghasilan jabatan, menciptakan kondisi sosial yang baik, menciptakan emosional yang cerdas, mencerdaskan intelektualitas yang baik, menciptakan karakter yang baik serta menciptakan spiritualitas yang baik. Sedangkan untuk para pejabat birokrat hendaknya melaporkan kekayaan yang dimiliki dimulai dari pertama menjabat, serta diberikan penyadaran etika, penyadaran moralitas, peningkatan keimanan, kelayakan hidup, melalui interaksi sosial, melalui keterbukaan, melalui pendidikan dan latihan, melalui kelompok informal dan formal.

Strategi pelayanan administrasi yang dapat meminimalisir patologi birokrasi baik yang bersifat mal administrasi maupun disfunction of Beureucracy antara lain dengan cara strategi penguatan peran birokrasi secara individu terkait dengan kualitas SDM dalam hal ini birokrasi dalam meminimalisir patologi birokrasi, strategi penguatan peran birokrasi secara organisasi dilakukan dengan cara melalui empat pendekatan antara lain: pendekatan struktural, pendekatan teknologi, pendekatan tugas, pendekatan orang, dan strategi penguatan birokrasi secara kesisteman dalam meminimalisir patologi birokrasi adalah sistem administrasi pelayanan prima pola layanan satu atap.

\section{Kesimpulan}

Patologi yang disebabkan karena kurangnya atau rendahnya pengetahuan dan keterampilan para petugas pelaksana kegiatan operasional jenis ini biasanya dikarenakan keinginan mendapatkan uang lebih, ini biasanya terjadi disebabkan oleh pihak baik masyarakat ataupun birokr:at diantaranya tidak mampu menjabarkan kebijaksanaan pimpinan, ketidak telitian, rasa puas diri, bertindak tanpa berfikir, kebingungan, sogok, mutu hasil pekerjaan rendah, kedangkalan, ketidaktepatan tindakan, inkompetensi, sikap ragu-ragu, bekerja tidak produktif, ketidakrapian, stagnasi. Sehingga terapi untuk jenis ini yang diderita oleh Birokrat Kan- 
Tersedia Online di http://journal.unismuh.ac.id/index.php/otoritas

Otoritas : Jurnal Ilmu Pemerintahan, 7 (1), April 2017, 18

tor Pertanahan kota Cimahi ini perlu disadarkan dari kedua belah pihak dengan cara memberikan pemahaman dan transparansi soal syarat-syarat, serta prosedur baik waktu dan biaya yang ditempuh sehingga dapat menanggulangi masalah penyogokan yang terjadi dan diterapkannya hukuman yang berat bagi oknum birokrat maupun masyarakat yang terbukti memberi sogok maupun yang diberi sogok sehingga menimbulkan efek jera serta kedepannya diharapkan tindakan preventif ini dapat mencegah terjadinya patologi birokrasi pada Kantor Pertanahan Kota Ciamis.

\section{Ucapan Terima Kasih}

Ucapan terima kasih dan doa kami haturkan kepada pihak yang membantu proses penelitian hingga proses publikasi pada Otoritas : Jurnal Ilmu Pemerintahan. Terima kasih secara khusus kami haturkan kepada Pimpinan dan Dosen Sejawat di Fakultas Ekonomi Universitas Putra Indonesia.

\section{Daftar Pustaka}

Creswell, W. J. (2009). Qualitative, Quantitive, and Mixed Methods Approaches. Thousand Oaks California: SAGE Publications.

Lukman, L. (2016). Profesionalisme Aparatur Pemerintahan Pada Kantor Dinas Catatan Sipil Kabupaten Kutai Kartanegara. Mahakam Fisipol, $5(1)$.

Rislan, R. (2016). Perilaku Birokrasi Pada Kantor Kecamatan Parigi Barat Kabupaten Parigi Moutong. Katalogis, 4(1).

Siagian, S. P. (1994). Patologi Birokrasi: Analisis, Identifikasi, dan Terapinya. Jakarta: Ghalia Indonesia.

Supardal, S. (2016). Penerapan ICT dalam Pelayanan Publik di Kabupaten Bantul. Otoritas: Jurnal Ilmu Pemerintahan, 6(2), 120-134.
Usman, J. (2011). Manajemen Birokrasi Profesional dalam Meningkatkan Pelayanan Publik. Otoritas: Jurnal Ilmu Pemerintahan, 1(2).

Sartika, D. (2016). Analisis Perilaku Birokrasi Dalam Penyelenggaraan Pelayanan Publik di Kelurahan Lambara Kecamatan Tawaeli. Katalogis, 1(7). 